\begin{tabular}{|c|c|c|c|}
\hline Brief-Illness Perception Questionnaire & $\begin{array}{c}\text { Men } \\
(\mathrm{n}=653)\end{array}$ & $\begin{array}{l}\text { Women } \\
(\mathrm{n}=154)\end{array}$ & $p$-value* \\
\hline & mean $\pm S D$ & mean $\pm S D$ & \\
\hline $\begin{array}{l}\text { Consequences } \\
(10=\text { severely affects life })\end{array}$ & $2.8 \pm 2.6$ & $3.8 \pm 3.0$ & $<0,01$ \\
\hline $\begin{array}{l}\text { Timeline } \\
\text { (10=will continue forever) }\end{array}$ & $6.9 \pm 3.7$ & $6.8 \pm 3.7$ & 0,87 \\
\hline $\begin{array}{l}\text { Personal control } \\
\text { (10=extreme amount) }\end{array}$ & $5.8 \pm 3.3$ & $5.3 \pm 3.5$ & 0,19 \\
\hline $\begin{array}{l}\text { Treatment control } \\
(10=\text { extremely helpful) }\end{array}$ & $6.8 \pm 3.0$ & $6.2 \pm 3.2$ & 0,08 \\
\hline $\begin{array}{l}\text { Identity } \\
\text { (10=many severe symptoms) }\end{array}$ & $3.3 \pm 2.9$ & $4.0 \pm 3.1$ & $<0,01$ \\
\hline $\begin{array}{l}\text { Concerns } \\
(10=\text { extremely concerned })\end{array}$ & $3.1 \pm 3.0$ & $3.8 \pm 3.3$ & $<0,01$ \\
\hline $\begin{array}{l}\text { Understanding } \\
(10=\text { very clearly })\end{array}$ & $5.9 \pm 3.2$ & $5.4 \pm 3.2$ & 0,26 \\
\hline $\begin{array}{l}\text { Emotional response } \\
(10=\text { extremely affected })\end{array}$ & $2.5 \pm 2.8$ & $3.1 \pm 3.1$ & $<0,01$ \\
\hline Questions: dietary changes, health care advice & Yes (\%) & Yes $(\%)$ & \\
\hline Have you reduced your intake of seafood? & $13 \%$ & $23 \%$ & $<0,01$ \\
\hline Have you reduced your intake of meat? & $19 \%$ & $41 \%$ & $<0,01$ \\
\hline Have you reduced your intake of organ meats? & $45 \%$ & $69 \%$ & $<0,01$ \\
\hline Have you reduced your intake of alcohol? & $44 \%$ & $48 \%$ & 0,47 \\
\hline Have you been advised by health care professionals about dietary changes? & $53 \%$ & $22 \%$ & $<0,01$ \\
\hline Have you been advised by health care professionals about weight loss? ${ }^{* *}$ & $65 \%$ & $47 \%$ & 0,04 \\
\hline
\end{tabular}

${ }^{*}$ Adjusted for age ${ }^{* \star}$ ) In those with BMI >30 kg/m² (men: 25\%, women: 40\%)

DOI: 10.1136/annrheumdis-2018-eular.5240

\section{SAT0736-HPR COMPARISON OF CORE STABILISATION AND BALANCE IN HEALTHY CONTROLS AND PATIENTS WITH ANKYLOSING SPONDYLITIS}

Y. Acar ${ }^{1}$, G. Can ${ }^{2}$, N. İlçin ${ }^{1} .{ }^{1}$ Physical Theraphy and Rehabilitation; ${ }^{2}$ Dokuz Eylül University, izmir, Turkey

Background: Ankylosing spondylitis is thought to cause balance problems. One component of balance is core stability. Core stability can be defined as the ability of the lumbopelvic-hip complex to control the trunk in response to disturbances generated by movement of the limbs, or other perturbations. There is limited literature about balance problems in AS. However there is no study investigating the effect of AS on core stability.

Objectives: The aim of this study was to investigate whether there is a difference in balance and core stabilisation between patients with ankylosing spondylitis(AS) and healthy individuals.

Methods: 64 patients( 40 male, 24 female) with AS and 64 healthy controls(39 male, 25 female) were included in this study. Demographic and physical characteristics(age, height, weigth, body mass index) were recorded. Static and dynamic balance was evaluated with Biodex Balance System SD. Anteroposterior(AP), mediolateral(ML) and overall(OA) postural stability indices were obtained with bilateral stance(stable and unstable platform), single leg stance(stable platform). Also overall,forward, backward, right and left limits of stability were evaluated. For evaluation core stabilisation static and dynamic core endurance tests and hip strength assessment were used. Modified sit-up test for dynamic core endurance and four static endurance tests (flexor endurance, extensor endurance and lateral side bridge tests) recommended by McGill et al for static core endurance were used. Hip strength measurement were assessed by hand-held dynamometer. Results: There were no significiant differences between groups regarding to gender,age, weight, height, body mass index $(\mathrm{p}<0,05)$. Overall, anteroposterior and mediolateral indices for bilateral stance(stable platform) and left leg stance(stable platform) were statistically better in control group $(p<0,05)$. Overall, forward, backward and right limits of stability scores were significantly higher in control group $(p<0,05)$. All of the core endurance tests were statistically better in control group $(p<0,05)$ table 1. Although all of the hip strength measuments were higher in control group than AS group, only statistically significiant difference was found in hip abduction strength $(p<0,05)$.

\begin{tabular}{lccc}
\multicolumn{4}{l}{ Abstract SAT0736HPR - Table 1. Comparison of the core endurance test results } \\
\hline & AS group $(\mathrm{n}=64)$ & Control group $(\mathrm{n}=64)$ & p value \\
& Median(IQR 25-75) & Median $($ IQR 25-75) & \\
\hline Trunk flexion & $34,10^{20,00-53,50}$ & $56,50\left({ }^{40,92-82,50}\right.$ & $0,00^{*}$ \\
Trunk extension & $43,30(22,06-69,75)$ & $86,00{ }^{71,25-106,62}$ & $0,00^{*}$ \\
Right side bridge(s) & $40,70^{23,12-59,95}$ & $61,00(43,5-84,38)$ & $0,00^{*}$ \\
Left side bridge(s) & $40,00^{25,70-58,92}$ & $61,5(45,20-82,25)$ & $0,00^{*}$ \\
Sit-up test & $17,50\left({ }^{7,00-26,75}\right.$ & $24\left({ }^{15,25-30,00}\right.$ & $0,004^{*}$
\end{tabular}

Mann Whitney U test. IQR: Interquartile Range * $p<0,05$

Conclusions: To our knowledge this is the first study that investigating core stability in AS patients. The findings of this study showed AS patients have reduced core endurance and hip abductor strenghth. According to our results AS has negative effect on bilateral stance, left leg stance postural stability and limits of stability.

\section{REFERENCES:}

[1] Akuthota V, et al. Core strengthening. Archives of physical medicine and rehabilitation 2004;85: 86-92.

[2] McGill SM, et al. Endurance times for low back stabilization exercises: clinical targets for testing and training from a normal database. Archives of physical medicine and rehabilitation 1999;80(8): 941-944.

Disclosure of Interest: None declared

DOI: 10.1136/annrheumdis-2018-eular.4453

Saturday, 16 JUNE 2018

\section{HPR Epidemiology and public health (including prevention)}

\section{SAT0737-HPR MEASURES OF PHYSICAL ACTIVITY AND FEAR AVOIDANCE IN PEOPLE WITH CHRONIC PAIN}

A. Bremander ${ }^{1,2,3}$, E. Haglund ${ }^{2,3}$, S. Bergman ${ }^{1,3,4}$. ${ }^{1}$ Department of Clinical Sciences, Section of Rheumatology, Lund; ${ }^{2}$ School of Business, Technology and Science, Halmstad University; ${ }^{3}$ RandD centre, Spenshult, Halmstad; ${ }^{4}$ Primary Health Care Unit, Department of Public Health and Community Medicine, Institute of Medicine, Sahlgrenska Academy, University of Gothenburg, Gothenburg, Sweden

Background: Lifestyle factors such as physical activity (PA) has the possibility to contribute to improved health and quality of life in the population as well as in 